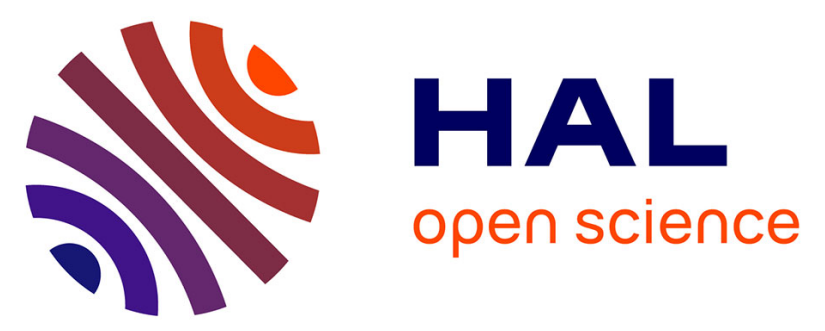

\title{
Multi-biomarker approach in wild European bullhead, Cottus sp., exposed to agricultural and urban environmental pressures: practical recommendations for experimental design
}

Sabrina Jolly, Anne Bado-Nilles, Florent Lamand, Cyril Turies, Edith Chadili, Jean-Marc Porcher, Stéphane Betoulle, Wilfried Sanchez

\section{To cite this version:}

Sabrina Jolly, Anne Bado-Nilles, Florent Lamand, Cyril Turies, Edith Chadili, et al.. Multi-biomarker approach in wild European bullhead, Cottus sp., exposed to agricultural and urban environmental pressures: practical recommendations for experimental design. Chemosphere, 2012, 87 (7), pp.675683. 10.1016/j.chemosphere.2011.12.055 . ineris-00961775

\section{HAL Id: ineris-00961775}

https://hal-ineris.archives-ouvertes.fr/ineris-00961775

Submitted on 20 Mar 2014

HAL is a multi-disciplinary open access archive for the deposit and dissemination of scientific research documents, whether they are published or not. The documents may come from teaching and research institutions in France or abroad, or from public or private research centers.
L'archive ouverte pluridisciplinaire HAL, est destinée au dépôt et à la diffusion de documents scientifiques de niveau recherche, publiés ou non, émanant des établissements d'enseignement et de recherche français ou étrangers, des laboratoires publics ou privés. 
1 Multi-biomarker approach in wild European bullhead, Cottus sp., exposed to 2 agricultural and urban environmental pressures: practical recommendations for experimental design

4

Sabrina Jolly ${ }^{1,2}$, Anne Bado-Nilles ${ }^{1,2}$, Florent Lamand ${ }^{3}$, Cyril Turies ${ }^{1}$, Edith Chadili ${ }^{1}$, Jean-

Marc Porcher ${ }^{1}$, Stéphane Betoulle ${ }^{2}$, Wilfried Sanchez ${ }^{1} *$

1. Institut National de l'Environnement Industriel et des Risques (INERIS), Unité

d'Ecotoxicologie in vitro et in vivo, BP2, 60550 Verneuil-en-Halatte, France

2. Université de Reims Champagne-Ardenne, Unité de Recherche Vignes et Vins de

Champagne - Stress et Environnement EA 2069, Laboratoire Ecologie-Ecotoxicologie, BP 1039, 51687 Reims Cedex 2, France

3. Office National de l'Eau et des Milieux Aquatiques (ONEMA), Délégation Inter-Régionale Nord-Est, 57155 Marly, France

* Corresponding author. Tel : +33 (0)3 44618121 ; Fax: +33 (0)344 556767

E-mail address : Wilfried.Sanchez@ineris.fr (W. Sanchez) 


\begin{abstract}
In freshwater ecosystems, a large number of chemical substances are able to disturb homeostasis of fish by modulating one or more physiological functions including the immune system. The aim of this study was to assess multi-biomarker responses including immunotoxicity induced by urban and agricultural pressure in European bullheads living in a small French river basin. For this purpose, a set of biochemical, immunological, physiological and histological parameters was measured in wild bullheads from five locations characterized by various environmental pressures. Moreover, to address effects of physiological status and contamination level variation on biomarker responses, fish were sampled during three periods (April, July and October). Results revealed a clear impact of environmental pressure on fish health and particularly on immunological status. An increase of EROD activity was recorded between upstream and downstream sites. Upstream sites were also characterized by neurotoxicological effects. Fish exhibited upstream/downstream variations of immunological status but strong differences were observed according to sampling season. Conversely, regarding biochemical and immunological effects, no significant response of physiological indexes was recorded related to environmental pressures. According to these results, the European bullhead appears as a valuable model fish species to assess adverse effects in wildlife due to urban and agricultural pressures.
\end{abstract}

Keywords: Fish, Immunotoxicity, European bullhead, Seasonal variability, Multi-biomarker approach 


\section{Introduction}

Adverse effects induced by several environmental pollutants, including widely used pesticides such as organophosphate, organochlorine or metals in aquatic ecosystems were assessed by many authors (Krzystyniak et al., 1995; Brousseau et al., 1997). Since these chemicals are known to induce disturbance of immune function in wild organisms, and especially in fish (Thomas, 1995; Dautremepuits et al., 2004), some immune parameters are proposed as ecotoxicological biomarkers. Currently, innate immune response was used as attractive biomarker for immunotoxicological risk assessment studies on mammals (Luster et al., 1988). This innate immune response is part of the first-line defense in the immune system of organisms acting against pathogens without prior exposure to any particular microorganism. Among them, respiratory burst, a crucial reaction of phagocytes to degrade internalized particles and bacteria (Huber et al., 2006), and lysozyme activity, a major parameter in the nonspecific immune defense (Magnadottir et al., 2006), are described as relevant indicators of toxicant exposure in aquatic organisms (Fournier et al., 2000; Bols et al., 2001; Reynaud and Deschaux, 2006).

Moreover, immune biomarkers appear as attractive effect-based monitoring tools due to their capacities to predict population disturbances by modification of disease susceptibility (Zelikoff, 1998; Bols et al., 2001). However, ecotoxicological status of water bodies cannot be reduced to measurement of immunomarkers while, i) immunotoxic pollutants are able to disturb other physiological functions such as reproduction (Kime, 1995) or xenobiotic metabolism (Whyte et al., 2000), and/or ii) many other pollutants are involved in environmental pollution. Also, immune parameters must be integrated in a multi-biomarker approach based on measurement of a set of complementary parameters. These parameters must be linked to several physiological processes able to reflect the effects of global 
contamination in investigated organisms (Flammarion et al., 2002; Sanchez et al., 2008a), such as biotransformation, oxidative stress and/or neurotoxic disturbances.

For this purpose, a set of complementary biomarkers involved in fish immunity (i.e.

respiratory burst and lysozyme activity) but also in organic compounds biotransformation (i.e. 7-ethoxyresorufin-O-deethylase, EROD; cytochrome P4503A activity, CYP3A, and glutathione-S-transferase, GST activities), protection against oxidative stress (i.e. glutathione peroxydase, GPx,) and neurotoxic disturbances (i.e. acetylcholinesterase activity, AChE) was measured to assess effects of field multi-contamination in wild European bullheads, Cottus sp., exposed to agricultural and urban environmental pressures. This fish was selected due to its wide repartition in French and European freshwater ecosystems. Moreover, this small benthic fish is characterized by a strong sedentary behavior (Reyjol et al., 2009) that allows assessing local environmental disturbances conversely to migratory or mobile fish species. Some studies have documented the physiological and biochemical responses of this species after field or laboratory chemical exposure and highlighted the bullhead as a relevant model fish species in ecotoxicology (Bucher et al., 1992, 1993; Dorts et al., 2011a, 2011b). This work was completed by histological analysis of gonads. Indeed, histology offers a powerful tool for sex determination, identifying the stage of gonad development, documenting presence of intersex and other abnormalities. Histological analysis of reproductive tissues can provide predictive information related to the fitness of organisms and their reproduction potential (Blazer, 2002). Gross indices such as Liver- and Gonado-Somatic Index (LSI and GSI, respectively) and Condition Factor (CF) were also determined. These integrative indicators serve to provide information on energy reserve, possible disease and general condition of fish (Mayer et al., 1992). The effect-based monitoring approach deployed in this study allows integrating effects of environmental pollutants in various biological levels (i.e. biochemical, histological, physiological and morphological). Three different seasons were also chosen: 
spring (April), summer (July) and autumn (October). In fact, environmental conditions, which are directly (temperature, photoperiod, precipitation, pathogens) or indirectly (anthropogenic pressures) controlled by the season, can affect fish physiology and health (Bowden et al., 2007).

\section{Materials and methods}

\subsection{Site descriptions}

This study was performed in the Vesle River basin located in Champagne-Ardenne region (Northeastern France). Five sites were investigated: Bouy, Prunay and Muizon located on the Vesle River; Courtagnon and Serzy in the tributary Ardre River (Fig. 1). The Bouy and Prunay sites, located upstream from the city of Reims, were highly influenced by intensive cereal farming and by agricultural (sugar beets, alfalfa, peas and potatoes; 70\% of land use) and viticultural practices (5.5\% of land use), respectively. Muizon station was chosen due to its urbanized area location (downstream from the city of Reims), where water quality has been classified as "bad" by the French Water Quality Monitoring Program (RNB) due to high concentration of Diuron, associated with high levels of nitrogen and phosphorous (SeineNormandie Water Agency, 2007). In the Ardre River, the upstream Courtagnon site was located in a forested sector without direct environmental inputs of chemicals, whereas Serzy station, situated downstream, was located in an intensive wine-growing area with "bad" water quality due to high concentrations of isoproturon, aminotriazole, glyphosate, atrazine and MCPA (Seine-Normandie Water Agency, 2007). Due distance between investigated sites and sedentary character of bullhead, investigated populations were isolated in each of the five stations.

\subsection{Fish collection and tissue sampling}


For each location, 12-20 adult European bullheads of both sexes (mean length $82 \pm 6 \mathrm{~mm}$ ) were caught by electrofishing, which seems to have no effect on immune parameters tested (Vanderkooi et al., 2001), in April, July and October 2010. Fish were immediately killed by spinal dislocation, weighed, measured and sexed. The liver, the gonads and approximately 10 $\mathrm{mg}$ of muscle were collected and weighed. The liver and the muscle were stored at $-80 \mathrm{C}$ for biochemical analysis, whereas the gonads were maintained in Bouin's fluid for histological analysis. Trunk kidneys were also removed under aseptic conditions and cut in two parts to measure immunological parameters. A piece of trunk kidney was stored in liquid nitrogen and another piece was pressed through sterilized nylon mesh (40 $\mu \mathrm{m}$, Dutscher) with Leibovitz 15 Medium (Sigma) containing heparin lithium (10 U.mL-1, Sigma), penicillin (500 U.mL-1, Biochrom AG) and streptomycin (500 $\mu \mathrm{g} . \mathrm{mL}-1$, Biochrom AG) to obtain leucocyte suspension (Secombes et al., 1990). Leucocytes were stored for 12 hours at $5 \pm 1{ }^{\circ} \mathrm{C}$ before measuring immune cellular responses.

\subsection{Morphometric indices}

As described by Janssen et al. (1995), CF were calculated as [100 x body weight $(\mathrm{g})] /$ length ${ }^{3}$ (cm)]. The LSI was calculated as the [100 x liver wet weight $(\mathrm{g})]$ / total body weight $(\mathrm{g})]$ (Sloof et al., 1983). GSI was calculated as [100 x gonad weight $(\mathrm{g})]$ / fish weight $(\mathrm{g})]$ (Lofts et al., 1966).

\subsection{Biochemical analysis}

Both liver and muscle were homogenized in an ice-cold potassium phosphate buffer $(0.1 \mathrm{M}$, pH 7.5) supplemented with $20 \%$ glycerol and $0.2 \mathrm{mM}$ phenylmethylsulfonyl fluoride (PMSF) in order to inhibit proteolysis. Homogenates were centrifuged at $10,000 \mathrm{~g},+4^{\circ} \mathrm{C}$ for $15 \mathrm{~min}$ and the resulting post-mitochondrial fraction was used for biomarker measurements. Protein 
concentration was determined using the method of Bradford (1976) with bovine serum albumin (Sigma Aldrich chemicals, France) as the standard. Hepatic activities of EROD, CYP3A, GST, GPx were assessed. Briefly, EROD activity was measured according the method developed by Flammarion et al. (1998a). The diluted samples at 25 to $100 \mu \mathrm{g}$ of proteins were added to phosphate buffer containing $8 \mu \mathrm{M}$ of 7-ethoxyresorufin and $0.5 \mathrm{mM}$ of NADPH. Formed resorufin was quantified by fluorimetric measurement with $530 \mathrm{~nm}$ wavelength excitation and $590 \mathrm{~nm}$ wavelength emission. Resorufin was used as standard, and results were expressed in pmol of resorufin $/ \mathrm{min} / \mathrm{mg}$ of proteins. CYP3A activity was measured according to Miller et al. (2000). The post-mitochondrial fraction at $60 \mu \mathrm{g}$ of proteins was added to $200 \mathrm{mM}$ of 7-benzyloxyfluoromethylcoumarin and $2 \mathrm{mM}$ of NADPH. The formation of 7-hydroxy-4-trifluoromethylcoumarin (HFC) is monitored by fluorescence using an excitation wavelength of $410 \mathrm{~nm}$ and an emission wavelength of $510 \mathrm{~nm}$. Data were expressed as pmol of HFC formed/min/mg of proteins using HFC as standard. GST activity assay was conducted according to Habig et al. (1974). The diluted samples at $12.5 \mu \mathrm{g}$ of proteins were mixed with $1 \mathrm{mM}$ of chloro dinitro benzene and $1 \mathrm{mM}$ of reduced glutathione. Enzymatic reaction was monitored spectrophotometrically at $340 \mathrm{~nm}$ and results were expressed in $\mathrm{U}$ of GST/g of proteins. The diluted samples at $56 \mu \mathrm{g}$ of proteins were used to determine GPx activity according to the method of Paglia and Valentine (1967). Cumene hydroperoxide was used as substrate and enzymatic activity was assessed at $340 \mathrm{~nm}$. Results were expressed in $\mathrm{U}$ of $\mathrm{GPx} / \mathrm{g}$ of proteins.

AChE activity was measured in muscle according to the method developed by Ellman et al. (1961). The formation of 5-thio-2-nitro-benzoic acid generated by the sample diluted at $5 \mu \mathrm{g}$ of proteins or by the standard of AChE from electric eel (Sigma-Aldrich Chemicals), was monitored at $405 \mathrm{~nm}$. The results were expressed as $\mathrm{U}$ of $\mathrm{AChE} / \mathrm{g}$ of proteins. 


\subsection{Immunological parameters}

To determine lysozyme concentration, the piece of kidney stored at $-80{ }^{\circ} \mathrm{C}$, was homogenized in an ice-cold potassium phosphate buffer $(0.05 \mathrm{M}, \mathrm{pH}$ 6.2). Homogenates were centrifuged at $3,450 \mathrm{~g},+4{ }^{\circ} \mathrm{C}$ for $30 \mathrm{~min}$ and the resulting supernatant was used for immune analysis. The protein concentration was determined and the lysozyme activity was measured by a slight modification of the turbidimetric assay described by Studnicka et al. (1986). Sample or lysozyme standard (Sigma-Aldrich) was added to Micrococcus lysodeikticus suspension $(0.2 \mathrm{~g} / \mathrm{L})$ and the decrease in absorbance was recorded at $450 \mathrm{~nm}$ by spectrophotometry. The results were expressed as $U$ of lysozyme/g of proteins.

Concerning determination of respiratory burst activity (Reactive oxygen species (ROS) production), leucocyte suspension samples were centrifuged for $10 \mathrm{~min}$ at $400 \mathrm{~g}$ at $4{ }^{\circ} \mathrm{C}$. The supernatant was eliminated and the leucocytes were re-suspended in $1 \mathrm{~mL}$ of $\mathrm{L} 15$ medium supplemented with heparin, penicillin and streptomycin. Viable cells were counted by trypan blue exclusion and the cell suspension was diluted with L15 medium to obtain 60,000 viable cells per well. Determination of respiratory burst activity (ROS production) was performed using a modification of the chemiluminescence method of Stave et al. (1983). Each assay well was filled with a volume of $160 \mu$ l containing cell suspension in L15 medium (60,000 cells), luminol $\left(20 \mu \mathrm{L}\right.$ at $2 \times 10^{-5} \mathrm{M}$ in L15 medium) and PMA (20 $\mu \mathrm{L}$ at $\left.125 \mathrm{ng} \cdot \mathrm{mL}^{-1}\right)$. Controls were carried out with L15 medium. Cellular baseline was determined at this zero time, PMA was immediately added and the level of intracellular luminescence was measured in both unstimulated and stimulated cells. Chemiluminescence was determined at $20^{\circ} \mathrm{C}$ with a microplate luminometer (VICTOR ${ }^{2}, 1420$ Multilabel counter). Data were collected every $1.30 \mathrm{~min}$ for $45 \mathrm{~min}$. The results were expressed in Relative Luminescence Units.

\subsection{Gonad histology}


Dissected tissues were fixed in Bouin's fluid for 24 hours, dehydrated through a series of ethanol, cleared with toluene and finally embedded in paraffin. Sections of $5 \mu \mathrm{m}$ in thickness were cut using a model RM2245 microtome (Leica Microsystems, Wetzlar, Germany) and stained with hematoxylin and eosin (HE). Gonad sections were then examined under a Zeiss Axioimager $\mathrm{z}_{1}$ light microscope (Zeiss $\mathrm{GmbH}$, Göttingen, Germany) and gonadal development stages were determined and adapted from the classification described by Jafri (1990). Oocyte maturation was divided into four different stages according to the cell size, the morphology and the extent of vitellus accumulation: primary oocytes (stage 1), previtellogenic oocytes (stage 2), secondary oocytes (stage 3) and degenerated oocytes (stage 4). Four spermatogenetic stages were differentiated according to the morphology and the size of the cells: spermatogonia (stage 1), spermatocytes (stage 2), spermatids (stage 3) and spermatozoids (stage 4). As several stages coexist in a given gonad, the most advanced stage occurring inside the gonad was chosen to characterize the sexual maturity of fish. The occurrence of abnormalities such as intersex, fibrosis and necrosis were noted.

\subsection{Statistical analysis}

All data are reported as mean \pm standard deviation and the SPSS 17.0 software was used for statistical analysis. Normal distribution of data was verified using Kolmogorov-Smirnov test. Since data sets did not have a normal distribution and homogeneity of variance, the data was $\log$-transformed using $\mathrm{F}(\mathrm{x})=\log (1+\mathrm{x})$, prior to parametric analysis. A two-way analysis of variance (ANOVA) was performed for each parameter using sites and gender as factors. When sites by gender interactions were significant $(\alpha=0.05)$, male and female data were treated separately. However, male and female LSI and GSI data were also treated separately due to physiological differences between genders. Biomarker responses measured at each 
sampling period were compared using one-way ANOVA followed by the Sidak test $(\alpha=$ $0.05)$.

\section{Results}

\subsection{Morphometric indices}

In April, length $(81.3 \pm 7.1 \mathrm{~mm})$, weight $(7.1 \pm 3.2 \mathrm{~g})$ and $\mathrm{CF}\left(1.3 \pm 0.2 \mathrm{~g} / \mathrm{cm}^{3}\right)$ were measured in adult European bullheads at each station and no significant differences were recorded among investigated sites. However, statistical analysis of seasonal variations (data not presented) showed that in July and October, Courtagnon's fish possessed a weak length and weight compared to other sites. Moreover, in July, the Vesle downstream site of Muizon had bigger bullheads than other stations, having the highest $\mathrm{CF}\left(1.6 \pm 0.9 \mathrm{~g} / \mathrm{cm}^{3}\right)$.

Among the investigated gross indices, LSI and GSI showed significant gender differences with high values in female fish compared to male. Assessment of seasonal variations showed that LSI values were lower in October compared to April and July whereas GSI data were lower in July than in April and October. Inter-site comparisons showed a lack of variation for LSI and GSI during the year. Nevertheless, statistical analysis of seasonal variations (data not presented) showed an increase of LSI in fish from Serzy collected either in April and October or in July, in fish located at Serzy, Bouy and Muizon. Concerning GSI, in April, only at the Vesle upstream sites of Serzy and Prunay female values were significantly higher than other stations tested; and in October, the male data were lower in Vesle than Ardre River (Table 1).

\subsection{Biochemical and immune biomarkers}

Only the three biotransformation enzymes tested (EROD, CYP3A and GST) and the lysozyme concentrations were gender dependent. In fact, high EROD, CYP3A and GST and low lysozyme activity were detected in male bullheads compared to female (Table 2 and 3). 
Moreover, in this study, all selected biomarkers were influenced by seasonal variation. In July, a decrease of biotransformation enzyme activities was recorded in both genders for EROD, CYP3A activities and in male for GST activity. This decrease of GST activity was also observed in October in both male and female bullheads. Conversely, high AChE and respiratory burst values were exhibited for bullheads caught in the same period. An increase of lysozyme and GPx activities was also noticed in July (Table 2 and 3).

Independent of seasonal variations, some modulations in biomarker responses were detected at the sites. For biochemical biomarkers (Table 2), in April and July, a gradient of EROD activity was observed in the Vesle and Ardre Rivers with significantly low values measured in fish from the agriculturally-contaminated site of Prunay. When CYP3A values were almost equal at each station, higher GST values were detected in April for Bouy's fish. In the same way, GPx values were higher in Bouy station from April to July. AChE activity was also modified with inhibition recorded in July for Vesle and Ardre upstream sites of Serzy, Prunay and Bouy stations and in October only for Serzy area. Finally, concerning immunomarkers (Table 3), an immunostimulation (respiratory burst and lysozyme concentration) was detected in July at Prunay station. Respiratory burst activity was also characterized by a decreasing trend along the Vesle River in October, with a minimal value of 4530 RLU max in Muizon. Conversely, bullheads sampled in April shown a trend of lysozyme increase along the Vesle River with a maximal concentration of $14.7 \mathrm{U} / \mathrm{g}$ at the Vesle downstream site of Muizon.

\subsection{Histological analysis of gonads}

For each gender and season, the forest site of Courtagnon site possessed specific stages of gonad development compared to others stations sampled where a similar repartition of testicular/ovary development was observed at each sampling date (Fig. 2) and without intersex (data not shown). Moreover, except for Courtagnon, several histological anomalies, 
such as fibrosis and necrosis, were also observed in bullhead gonads at all sites with a significant gender difference, i.e. female gonads exhibited more anomalies than male gonads (Table 4).

More specifically for male gonads, in April, approximately $30 \%$ of spermatids and $70 \%$ of spermatozoids were detected in the Serzy, Bouy, Prunay and Muizon areas, whereas $100 \%$ of spermatozoids were shown at the Courtagnon station. In July, sites were characterized by the presence of spermatogonia (approximately $35 \%$ ) and spermatocytes (approximately $52 \%$ ). At this time, only two sites, Serzy and Prunay, still possessed fish with few spermatozoids (approximately $31 \%$ ) in their testes. Moreover, the Courtagnon station was clearly dissimilar, with absence of spermatocytes and with a higher percentage of spermatozoids (57\%) than spermatogonia (43\%). Finally, in October, fish testicles were all in the spermatocyte stage and only Bouy and Muizon possessed some organisms in the spermatid stage (approximately $57 \%$ ) (Fig. 2). Moreover, during the entire year, a higher percentage of fish with parasperm (> 50\%) was detected at each sampling area with a maximum values $(>80$ $\%)$ in April and October (data not shown).

Concerning female gonads, in April, ovary atresia was recorded. However, Prunay possessed some fish $(63 \%)$ with secondary oocyte stages; and Bouy was clearly different with the presence of bullhead with only the first three gonad development stages. In July, the Courtagnon area again showed $100 \%$ of fish with ovary atresia, whereas at the four other sites each stage of gonad development was detected. Pre-vitollogenic (approximately $52 \%$ ) and secondary oocytes (approximately $48 \%$ ) were specifically detected in female fish sampled in October. However, some variations were observed in fish from Courtagnon that exhibited gonads with only secondary (approximately $60 \%$ ) and degenerated oocytes (approximately $40 \%$ ) (Fig. 2). 


\section{Discussion}

\subsection{Basal values and reference selection for multi-biomarker data analysis}

Two strategies based on absolute reference definition or on upstream/downstream approach are commonly used to analyze biomarker responses. Both interpretation methods are considered complementary due to the level of information supported by these strategies (Sanchez et al., 2010). In this work, the site of Courtagnon could be considered a valuable study area for establishing an absolute reference in the Vesle River basin. Indeed, this site is located in the forested upper area of a Vesle tributary and is not exposed to point source chemical pollutants. However, examination of the reproductive cycle of Courtagnon's bullhead, which resulted from a relationship between variations of bullhead reproductive status and histological examination, showed a clear disturbance of this parameter, with presence of fish exhibiting gonads with secondary or degenerated oocytes in all sampling seasons (Fig. 2). This result could be explained by the specific hydrological status of the Courtagnon site. The site is located near the source of the Ardre River and could be characterized by a lack of temperature variation as observed in other similar sampling locations such as the Vallon du Vivier (Sanchez et al., 2008b) where signs of bullhead reproduction were recorded throughout the year (ONEMA, personal communication). In other stations investigated in this study, the reproductive cycle of bullheads appeared to be in accordance with data reported in the scientific literature describing a spawning period between April and July (Zbinden et al., 2004). Before spawning period (April), male gonads possess spermatids, spermatozoids and parasperm and, after spawning period (July), the gametogenesis began again at all sites with the presence of spermatogonia and/or spermatocytes and a reduction of parasperm presence (data not shown). In the same way, secondary oocytes or atresia were recorded in female ovaries in April and July and a new reproductive cycle was begun with the presence of primary and pre-vitellogenic oocytes. Due 
to the interaction between reproduction and other physiological functions investigated in this study, such as immunity (Harris and Bird, 2000) and biotransformation (Kirby et al., 2007), fish from Courtagnon cannot be used to establish reference values for bullhead biomarkers in the Vesle River basin. To bridge this gap, a relative reference system based on an upstream/downstream approach was proposed in this study to analyze multi-biomarker responses. In this context, classification of real induction or inhibition seems to be difficult but this strategy allows for integrating the effects induced by pollution and other environmental factors in the upstream area.

\subsection{Relationship between environmental pressure and fish responses}

A noteworthy fact was that the biomarker response patterns noticed along the Vesle River showed a clear difference between upstream sites characterized by agricultural pressure (Prunay and Bouy) and the downstream site of Muizon affected by urban pressure (Table 2), reflecting adverse effects of environmental pollution on wild fish health. This statement is particularly true in April for biotransformation enzymes and in July and October for AChE activity.

A gradient effect was recorded for the two immunobiomarkers tested, including respiratory burst and lysozyme activities (Table 3), with a decrease of responses between upstream and downstream. As described by several authors (Fournier et al., 2000; Reynaud and Deschaux, 2006), this immunosuppressive effect was correlated with exposure to various chemicals discharged in the river, such as heavy metals, PAHs, PCBs and pesticides. The diminution of lysozyme activity could induce an inhibition of their hydrolysis catalyzation of $1,4-\beta$-linkages between $\mathrm{N}$-acetylmuramic acid and $\mathrm{N}$-acetyl-D-glucosamine residues (Yano, 1996). This action highlighted a direct decrease of pathogen membrane destruction. Moreover, a reduction of phagocytosis capacities was indirectly proved by a decrease of respiratory burst, a crucial 
reaction to degraded internalized pathogens (Huber et al, 2006), and lysozyme activity, which is an activator of phagocytes and acts as an opsonine (Yano, 1996). Therefore, this disturbance of fish immunity denoted a reduction of pathogen destruction and an increase of fish susceptibility to pathogen aggressions.

Concerning biochemical biomarkers, a similar response profile was observed for each parameter tested (EROD, CYP3A, GST, GPx and AChE). In the present work, in wild bullheads an inhibition of EROD activity was suggested at upstream sites. As described previously, this recognized biomarker of exposure to dioxin-like compounds can be inhibited by several pollutants widely used in agricultural activities, such as copper (Flammarion et al., 1996; Viarengo et al., 1997) or pesticides (Flammarion et al., 1998b), and is strongly detected in the Vesle River due to viticultural and agricultural pressures (ONEMA, personal communication). In addition to the destabilization of catalytic activity, phases I and II of pollutant detoxification and hepatic steroid catabolism were also modified in downstream stations compared to upstream sites, due to a trend of modulation of CYP3A and GST activities, respectively. Moreover, GST is known to be involved in the cellular defense against oxidative stress by conjugating electrophilic compounds to glutathione (GSH) (Habig et al., 1974). Since, oxidative stress could be induced by some pollutants, such as copper and pesticides (Dautremepuits et al., 2004; Ahmad et al., 2005), an increase of antioxidant enzymes, such as GPx, could be detected at downstream stations. These enzymes permit the reduction of intermediate products to maintain cellular viability (Reischl et al., 2007) and to decrease oxidative species produced during pollutant metabolization in order to restrain cytochrom P450 decline (Della Torre et al., In Press). Finally, a decrease of AChE activity in bullheads from upstream sites was also observed. The AChE activity is frequently described as a relevant and sensitive parameter to assess exposure to neurotic pollutants and particularly pesticides in wild fish (Payne et al., 1996). Moreover, as obtained in bullhead from sites 
receiving agricultural run-off in the Vesle and Ardre Rivers, an association between induction of oxidative stress and inhibition of AChE activity in fish exposed to various pesticides such as chlorpyrifos, diazinon and glyphosate (Modesto and Martinez, 2010; Oruç, 2010) was demonstrated.

To complete biochemical and immunological analysis, physiological indicators including LSI, GSI and CF were measured in wild bullheads. These parameters are classically used as integrative indicators that provide valuable information on fish heath and reproductive status. However, due to influence of biotic and environmental factors on these parameters, they are considered as bad discriminators (Sanchez et al., 2008a). In the present work, few significant inter-site variations were recorded for these physiological indexes and observed differences were between fish from both sites of Ardre river and between both Ardre and Vesle rivers. Also, these results could be explained by hydromorphological variations previously described. To our knowledge, no data is available on basal level of somatic indexes and CF in the European bullhead. Consequently, it is not easy to address accurately these physiological changes.

\subsection{Seasonal variability: a complex effect}

Seasonal effects on biomarker responses are well described in fish (Sanchez et al., 2008b). Indeed, this knowledge is indispensable for a better application and analysis of biomarkers in environmental risk assessment. The present work provided relevant data related to interaction between fish biochemical responses and biotic or environmental factors. A noteworthy fact was that seasonal and also gender effects recorded in the bullhead are in accordance with data available in the scientific literature for other model fish species. A clear gender effect was observed for biotransformation enzyme responses with high values in male fish. This extensively described result is explained by the negative effect of endogenous estradiol on 
cytochrome P-450 catalytic activity (Arukwe and Goksøyr, 1997). This effect is most pronounced during breeding periods. As phase I biotransformation enzymes, GST activity seems to be correlated to spawning period with lower values recorded in fish collected in October. The same pattern was reported in Anguilla anguilla and Mugil cephalus (Gorbi et al., 2005) but the involved mechanisms are not understood. A seasonal variation was also measured for GPx activity. If less information is available on seasonal changes of the antioxidant enzymes in fish, any studies reported a similar seasonal pattern in fish such as the three-spined stickleback and explained this effect by the involvement of GPx in steroid metabolism (Sanchez et al., 2007). In light of this data, several authors recommend measurement of biomarkers outside the reproductive period to decrease the number of sampled fish and to increase statistical power due to a low variability of investigated responses (Flammarion and Garric, 1997; Sanchez et al., 2008a). However, in the present study, more inter-site differences were recorded in April than in July and October especially for EROD activity, oxidative stress parameters and neurotoxicity biomarkers. A decrease of respiratory burst was observed in fish collected in October compared to July. A number of reports have shown that abiotic factors (e.g. water temperature, photoperiod, pollution, diet) as well as biotic factors (e.g. pathogens) directly or indirectly controlled by the season cycle, affect the immune function of fish (Saha et al., 2002). These response profiles could be explained by the seasonality of pollution due to agricultural practices in the investigated area since viticulture prophylactic treatments are applied in spring. Also, this study argues for a design of freshwater risk assessment studies based on variability of environmental pressures. Several sources of pollutants such as agriculture, but also urban activities (Hemming et al., 2004; Miège et al., 2006), are known to exhibit strong temporal variability. In this context, a monitoring design based only on fish physiological cycles appears as not relevant and could lead to erroneous diagnosis of contamination effects on wildlife. However, a better knowledge 
of model fish species physiology must be considered as a major requirement for biomarker deployment.

\section{Conclusions}

To summarize, the present study was designed to assess multi-biomarker responses including immunotoxicity induced by urban and agricultural pressure in European bullheads living in a small French river basin, the Vesle watershed. Results revealed various kinds of biological effects due to environmental pressure on fish health and particularly on immunological status. This study also highlighted the high variability of biomarker responses between sites (downstream/upstream effect) and seasons (environmental condition impact). Some cautions about selection of reference sites and seasons to determine freshwater risk assessment were also given:

i) Reference site must be established according to the function of chemical and biological qualities of area, but in a river basin monitoring context, an upstream/downstream approach appears as a powerful methodology to analyze multi-biomarker responses and integrate the complexity of contamination;

ii) Historically, measurement of multi-biomarker responses was performed according to fish physiological cycles. However, seasonal variability of environmental pressure cannot be ignored in the design of monitoring programs.

\section{Acknowledgements}

This work was supported by the French Ministry of Ecology and Sustainable Development (Programme 181-DRC43 and Programme 190 Ecotoxicology). We thank the technical staff from the "Office National de l'Eau et des Milieux Aquatiques" for their assistance in fish sampling. The authors thank also xxx for reviewing English language of this manuscript. 
Ethical considerations: Procedures described in the present paper were conducted in accordance with laws and regulations controlling animal experiments in France. All experimental protocols were approved by the Ethical Committee of the French National Institute of Industrial Environment and Risks.

\section{References}

Ahmad. I., Oliveira, M., Pacheco, M., Santos, M.A., 2005. Anguilla anguilla L. oxidative stress biomarkers responses to copper exposure with or without b-naphthoflavone preexposure. Chemosphere 6, 267-275.

Arukwe, A., Goksøyr, A., 1997. Changes in three hepatic cytochrome P450 subfamilies during a reproductive cycle in turbot (Scophthalmus maximus L.). J. Exp. Zool. 277,313325.

Blazer, V.S., 2002. Histopathological assessment of gonadal tissue in wild fishes. Fish Physiol. Biochem. 26, 85-101.

Bols, N.C., Brubacher, J.L., Ganassin, R.C., Lee, L.E.J., 2001. Ecotoxicology and innate immunity in fish. Dev. Comp. Immunol. 25, 853-873.

Bowden, T.J., Thompson, K.D., Morgan, A.L., Gratacap, R.M.L., Nikoskelainen, S., 2007. Seasonal variation and the immune response: A fish perspective. Fish Shellfish Immunol. $22,695-706$.

Bradford, M.M., 1976. A rapid and sensitive method for the quantitation of microgram quantities of protein utilizing the principle of protein-dye binding. Anal. Biochem.72, 248254.

Brousseau, P., Dunier, M., Deschaux. P., De Guise, S., Krzystyniak, K., Fournier, M., 1997. Marqueurs immunologiques. In: Lagadic L, Caquet T, Amiard JC, Ramade F. 
Biomarqueurs en écotoxicologie, aspects fondamentaux. Londres, Paris, New York: Masson. p. 287-314.

Bucher, F., Hofer, R., El-Matbouli, M., 1992. Prevalence and pathology of Zschokkella nova (Myxosporea) in the liver of bullhead Cottus gobio from a polluted river. Dis. Aquat. Org. 14,137-143.

Bucher. F., Hofer, R., Krumschnabel, G., Doblander, C. 1993. Disturbances in the prooxidant - antioxidant balance in the liver of bullhead (Cottus gobio L.) exposed to treated paper mill effluents. Chemosphere 27,1329-1338.

Dautremepuits, C., Paris-Palacios, S., Betoulle, S., Vernet, G., 2004. Modulation in hepatic and head kidney parameters of carp (Cyprinus carpio L.) induced by copper and chitosan. Comp. Biochem. Physiol. C: Toxicol. Pharmacol.137, 325-333.

Della Torre, C., Monti, M., Focardi, S., Corsi, I., in press. Time-dependent modulation of cypla gene transcription and EROD activity by musk xylene in PLHC-1 and RTG-2 fish cell lines. Toxicol. in Vitro.

Dorts, J., Kestemont, P., Dieu, M., Raes, M., Silvestre, F., 2011a. Proteomic response to sublethal cadmium exposure in a sentinel fish species, Cottus gobio. J. Proteome Res. 10, $470-478$.

Dorts, J., Kestemont, P., Marchand, P.A., D'Hollander, W., Thezenas, M.L., Raes, M. et al. 2011b. Ecotoxicoproteomics in gills of the sentinel fish species, Cottus gobio, exposed to perfluorooctane sulfonate (PFOS). Aquat. Toxicol. 103, 1-8.

Ellman, G.L., Courtney, K.D., Andres, V.J., Featherstone, R.M., 1961. A new and rapid colorimetric determination of acetylcholinesterase activity. Biochem. Pharmacol. 7, 88-95.

Flammarion, P., Migeon, B., Garric, B., 1996. Join effect of copper sulphate and methidathion on rainbow trout (Oncorhynchus mykiss) EROD and AChE activities. Bull. Environ. Contam. Toxicol. 56, 440-445. 
Flammarion, P., Garric, J., 1997. Cyprinids EROD activities in low contaminated rivers: a relevant statistical approach to estimate reference levels for EROD biomarker ? Chemosphere 35, 2375-2388.

Flammarion, P., Migeon, B., Garric, J., 1998a Statistical analysis of cyprinid ethoxyresorufinO-deethylase data in a large French watershed. Ecotox. Environ. Safe. 40, 144-153.

Flammarion, P., Migeon, B., Urios, S.B., Morfin, P., Garric, J., 1998b. Effect of methidathion on the cytochrome P-450 1A in the cyprinid fish gudgeon (Gobio gobio). Aquat. Toxicol. 42, 93-102.

Flammarion, P., Devaux, A., Nehls, S., Migeon, B., Noury, P., Garric, J., 2002. Multibiomarker responses in fish from the Moselle River (France). Ecotox. Environ. Safe. $51,145-153$.

Fournier, M., Cyr, D., Blakley, B., Boermans, H., Brousseau, P., 2000. Phagocytosis as a biomarker of immunotoxicity in wildlife species exposed to environmental xenobiotics. Am. Zool. 40, 412-420.

Gorbi, S., Baldini, C., Regoli, F., 2005. Seasonal variability of metallothioneins, cytochrome P450, bile metabolites and oxyradical metabolism in the European eel Anguilla anguilla L. (Anguillidae) and striped mullet Mugil cephalus L. (Mugilidae). Arch. Environ. Contam. Toxicol. 49, 62-70.

Habig, W.H., Pabst, M.J., Jakoby, W.B., 1974. Glutathione S-Transferases. The first enzymatic step in mercapturic acid formation. J. Biol. Chem. 249, 7130-7139.

Harris, J., Bird, D.J., 2000. Modulation of the fish immune system by hormones. Vet. Immunol. Immunop.77, 163-176.

Hemming, J.M., Allen, H.J., Thuesen, K.A., Turner, P.K., Waller, W.T., Lazorchak, J.M. et al., 2004. Temporal and spatial variability in the estrogenicity of a municipal wastewater effluent. Ecotox. Environ. Safe. 57, 303-310. 
Huber, K., Krotz-Fahning, M., Hock, B., 2006. Respiratory burst as a biomarker for stress responses. Protoplasma 229, 221-224.

Jafri, S.I.H., 1990. Gametogenesis in roach, Rutilus rutilus (L.) (Cyprinidae: Teleostei). Pak. J. Zool. 22, 361-377.

Janssen, P.A.H., Lambert, J.G.D., Goos, H.J.T., 1995. The annual ovarian cycle and the influence of pollution on vitellogenesis in the flounder, Pleuronectes flesus. J. Fish Biol. $47,509-523$.

Kime, D.E., 1995. The effects of pollution on reproduction in fish. Rev. Fish Biol. Fish. 5, 5296.

Kirby, M.F., Smith, A.J., Rooke, J., Neall, P., Scott, A.P., Katsiadaki, I., 2007. Ethoxyresorufin-O-deethylase (EROD) and vitellogenin (VTG) in flounder (Platichthys flesus): System interaction, crosstalk and implications for monitoring. Aquat. Toxicol. 81, $233-244$.

Krzystyniak, K., Tryphonas, H., Fournier, M., 1995. Approaches to the evaluation of chemical-induced immunotoxicity. Environ. Health. Perspec. 103, 17-22.

Lofts, B., Pickford, G.E., Atz, J.W., 1966. Effects of methyl testosterone on the testes of a hypophysectomized cyprinodont fish, Fundulus heteroclitus. Gen. Comp. Endocr. 6, 7488.

Luster, M.I., Munson, A.E., Thomas, P.T., Holsapple, M.P., Fenters, J.D., White, K.L. et al., 1988. Development of a testing battery to assess chemical-induced immunotoxicity: National Toxicology Program's guidelines for immunotoxicity evaluation in mice. Fundam. Appl. Toxicol. 10, 2-19.

Magnadottir, B., 2006. Innate immunity of fish (overview). Fish Shellfish Immunol. 20, 137151. 
Mayer, F.L., Versteeg, D.J., Mac Kee, M.J., Folmar, L.C., Graney, R.L., Mac Cume, D.C. et al. 1992. Physiological and nonspecific biomarkers. In: Huggett, R.J., Kimerle, R.A., Mehrle, P.M., Bergman, H.L. Biomarkers: biochemical, physiological and histological markers of anthropogenic stress. Boca Raton: Lewis Publishers p. 5-86.

Miège, C., Favier, M., Brosse, C., Canler, J.P., Coquery, M., 2006. Occurrence of betablockers in effluents of wastewater treatment plants from the Lyon area (France) and risk assessment for the downstream rivers. Talanta 70, 739-44.

Miller, V.P., Stresser, D.M., Blanchard, A.P., Turner, S.D., Crespi, C.L., 2000. Fluorimetric high-throughput screening for inhibitors of cytochrome P450. Ann. N.Y. Acad. Sci. 919, 26-32.

Modesto, K.A., Martinez, C.B.R., 2010. Roundup® causes oxidative stress in liver and inhibits acetylcholinesterase in muscle and brain of the fish Prochilodus lineatus. Chemosphere 78, 294-299.

Oruç, E.O., 2010. Oxidative stress, steroid hormone concentrations and acetylcholinesterase activity in Oreochromis niloticus exposed to chlorpyrifos. Pest. Biochem. Physiol. 96, 160166.

Paglia, D.E., Valentine, W.N., 1967. Studies on the quantitative and qualitative characterization of erythrocyte glutathione peroxidase. J. Lab. Clin. Med. 70, 158-169.

Payne, J.F., Mathieu, A.W.M., Fancey, L.L., 1996. Acetylcholinesterase, an Old Biomarker with a New Future? Field Trials in Association with Two Urban Rivers and a Paper Mill in Newfoundland. Mar. Pollut. Bull. 32, 225-231.

Reischl, E., Dafre, A.L., Franco, J.L., Wilhelm Filho, D., 2007. Distribution, adaptation and physiological meaning of thiols from vertebrate hemoglobins. Comp. Biochem. Physiol. C: Toxicol. Pharmacol. 146, 22-53. 
Reyjol, Y., Léna, J.P., Hervant, F., Pont, D., 2009. Effects of temperature on biological and biochemical indicators of the life-history strategy of bullheads Cottus gobio. J. Fish Biol. 75, 1427-1445.

Reynaud, S., Deschaux, P., 2006. The effects of polycyclic aromatic hydrocarbons on the immune system of fish: A review. Aquat. Toxicol. 77, 229-238.

Saha, N.R., Usami, T., Suzuki, Y., 2002. Seasonal changes in the immune activities of common carp (Cyprinus carpio). Fish Physiol. Biochem. 26, 379-387.

Sanchez, W., Ait-Aissa, S., Palluel, O., Ditche, J.M., Porcher, J.M., 2007. Preliminary investigation of multi-biomarker responses in three-spined stickleback (Gasterosteus aculeatus L.) sampled in contaminated streams. Ecotoxicology16, 279-287.

Sanchez, W., Katsiadaki, I., Piccini, B., Ditche, J.M., Porcher, J.M., 2008a. Biomarker responses in wild three-spined stickleback (Gasterosteus aculeatus L.) as a useful tool for freshwater biomonitoring: A multiparametric approach. Environ. Int. 34, 490-498.

Sanchez, W., Piccini, B., Ditche, J.M., Porcher, J.M., 2008b. Assessment of seasonal variability of biomarkers in three-spined stickleback (Gasterosteus aculeatus L.) from a low contaminated stream: Implication for environmental biomonitoring. Environ. Int. 34, 791-798.

Sanchez, W., Piccini, B., Maillot-Marechal, E., Porcher, J.M., 2010. Comparison of two reference systems for biomarker data analysis in a freshwater biomonitoring context. Environ. Int. 36, 377-382.

Secombes, C.J., 1990. Isolation of salmonid macrophages and analysis of their killing activity. In: Van Muiswinkel WB. Techniques in Fish Immunology. Fair Haven: SOS Publication. p. 101-103.

Seine-Normandie Water Agency, 2007. Aisne Vesle Suippe. http://www.eau-seinenormandie.fr/fileadmin/mediatheque/vallees-doise/ComGeo/ComGeo_2007_Mars/ FICHES/Fiches_Eaux_SUP/EAUX_SUP_AISNE_V_S.pdf 
Sloof, W., Van Kreijl, C.F., Baars, A.J., 1983. Relative liver weights and xenobioticmetabolizing enzymes of fish from polluted surface in the Netherlands. Aquat. Toxicol. 4, $1-14$.

Stave, J.W., Roberson, B.S., Hetrick, F.M., 1983. Chemiluminescence of phagocytic cells isolated from the pronephros of striped bass. Dev. Comp. Immunol. 7, 269-276.

Studnicka, M., Siwicki, A., Ryka, B., 1986. Lysozyme level in carp (Cyprinus carpio L.). Bamidgeh 2, 22-25.

Thomas, P., 1995. Pesticide-induced Immunotoxicity: Are great lakes residents at risk? Environ. Health Perspect. 103, 55-61.

Vanderkooi, S.P., Maule, A.G., Schreck, C.B., 2001. The effect of elestroshock on immune function and disease progression in juvenile spring chinook salmon. T Am. Fish Soc. 130, $397-408$.

Viarengo, A., Bettella, E., Fabbri, R., Burlando, B., Lafaurie, M., 1997. Heavy metal inhibition of EROD activity in liver microsomes from the Bass Dicentrarchus labrax exposed to organic xenobiotics: Role of GSH in the reduction of heavy metal effect. Mar. Environ. Res. 44, 1-11.

Whyte, J.J., Jung, R.E., Schmitt, C.J., Tillitt, D.E., 2000. Ethoxyresorufin-O-deethylase (EROD) activity in fish as a biomarker of chemical exposure. Crit. Rev. Toxicol. 30:347570.

Yano, T., 1996. The nonspecific immune system: Humoral defense. In: Iwama, G., Nakanishi, T. The fish immune system: organism, pathogen and environment. San Diego, California: Academic Press. p. 106-159.

Zbinden, S., Pilotto, J.D., Durouvenoz, V., 2004. Biologie, menaces et protection du chabot (Cottus gobio) en Suisse. L'environnement pratique 77, 1-42. 
Zelikoff, J.T., 1998. Biomarkers of immunotoxicity in fish and other non-mammalian sentinel

614 species: predictive value for mammals? Toxicology 129, 63-71.

615 


\section{Figure Legends}

Fig. 1. Sampling sites on Vesle river system, with $A=$ localization of sites in France and $B=$

619 localization of the selected sampling sites in Vesle basin.

620

Fig. 2. Distribution of gonadal development stages in male and female bullheads sampled in

622

623 April, July and October 2010 from Courtagnon, Serzy, Bouy, Prunay and Muizon.

In male bullhead: stage $1=$ spermatogonia, stage $2=$ spermatocytes, stage $3=$ spermatids and stage $4=$ spermatozoids.

In female bullhead: stage $1=$ primary oocytes, stage $2=$ pre-vitellogenic oocytes, stage $3=$ secondary oocytes and stage $4=$ degenerated oocytes.

7

.

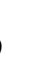

0

(631

632

6

.




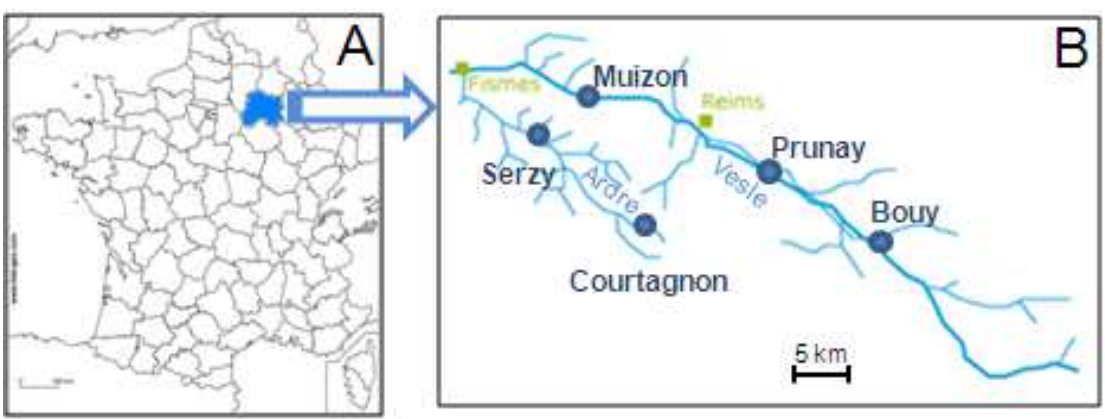

643 Fig. 1.

644

645

646

647

648

649

650

651

652

653

654

655

656

657

658

659

660

661

662 
Males

Females

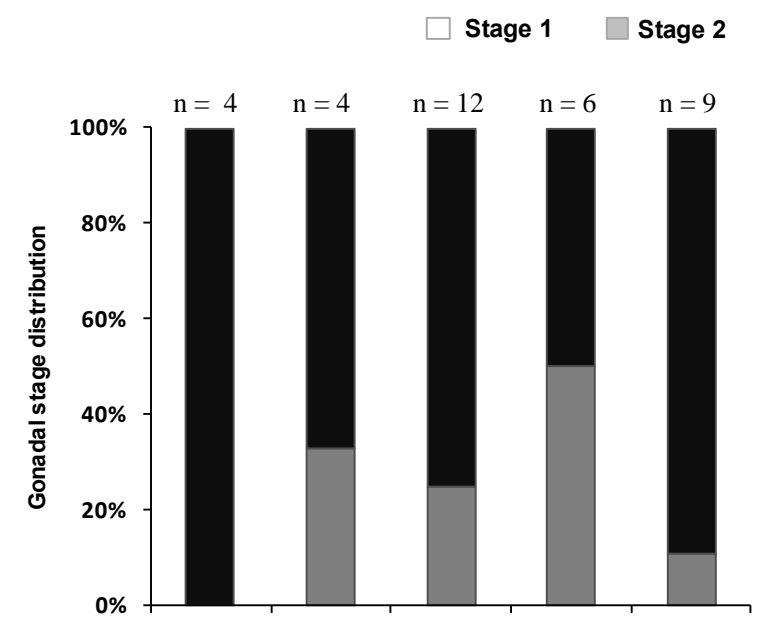

Stage $3 \square$ Stage 4
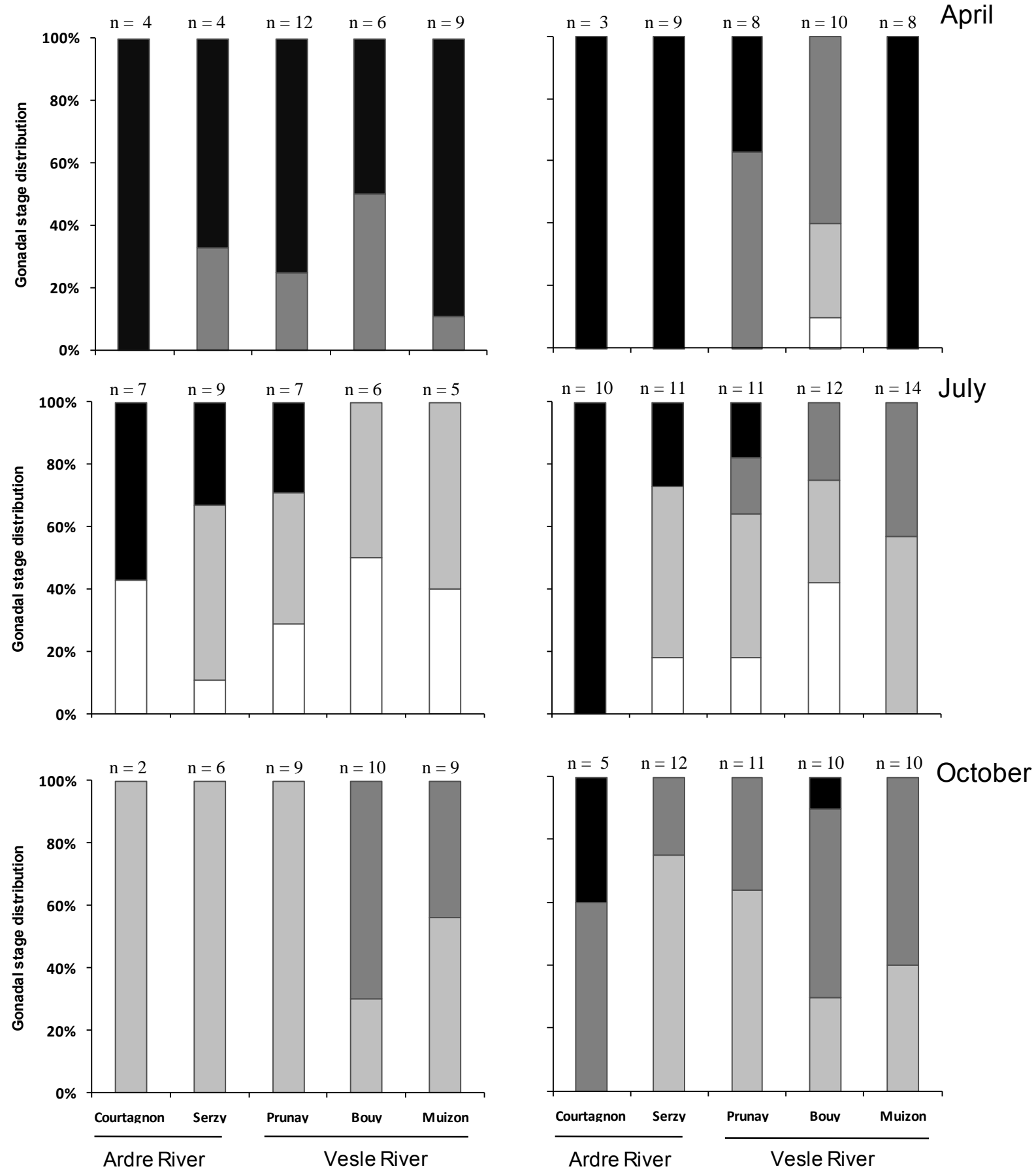

Fig. 2. 